\title{
Non-Wh Internal and External Topics in Classical Chinese and Their Similarity to Equivalent Constructions in Modern Mandarin
}

\author{
Aiqing Wang \\ Lancaster University, UK \\ aiqing.wang@lancaster.ac.uk
}

DOI: $\underline{\text { http://doi.org/ 10.36892/ijlls.v2i4.405 }}$

\begin{tabular}{ll}
$\begin{array}{l}\text { Received: } \\
\text { 04/04/2020 }\end{array}$ & An this paper I argue that non-wh internal and external topics in Classical \\
& Chinese can be analysed in parallel with their counterparts in modern \\
Accepted: & Mandarin. I first scrutinise pronoun fronting in the context of negation in \\
06/08/2020 & Classical Chinese, and propound that it is on a par with object preposing in \\
& modern Mandarin that is argued to be internal topics (Paul 2002). I then \\
\hline Keywords: & discuss non-interrogative elements base-generated and moved to the CP \\
Classical Chinese, & domain and illustrate their topical properties. Base-generated topics in \\
modern Mandarin, & Classical Chinese are Aboutness topics which permit DPs exclusively. In \\
pronoun fronting to & terms of moved external topics, they are constituted of preposed objects and \\
negation, internal & preposed predicates: the former allow DPs and TPs, whereas the latter allow \\
topics, external & DPs and AdjPs. Moreover, moved topics can be further divided into Hanging \\
topics, non-wh & Topics and Left Dislocation Topics, similar to those in modern Mandarin.
\end{tabular}

\section{INTRODUCTION}

The Chinese language is usually divided into Ancient Chinese (古代漢語 gudai hanyu) and Contemporary Chinese (現代漢語 xiandai hanyu). The historical time periods of Ancient Chinese are shown below (Aldridge 2013):

Table: Historical periods of Ancient Chinese

\begin{tabular}{|c|c|c|}
\hline Subdivision & Timespan & Dynasty \\
\hline Pre-Archaic & $14^{\text {th }}$ B BC- $11^{\text {th }} c$ BC & Shang \\
\hline Early Archaic & $10^{\text {th }} c$ BC- $6^{\text {th }} c B C$ & Zhou \\
\hline Late Archaic & $5^{\text {th }} \mathrm{c} \mathrm{BC}-3^{\text {rd }} c$ BC & Warring States \\
\hline Early Middle Chinese & $2^{\text {nd }} c B C-2^{\text {nd }} c A D$ & Han \\
\hline Middle Chinese & $3^{\text {rd }} \mathrm{c} A D-6^{\text {th }} c A D$ & Six Dynasties \\
\hline Late Middle Chinese & $7^{\text {th }} \mathrm{c}$ AD- $10^{\text {th }} \mathrm{c}$ AD & Tang \\
\hline
\end{tabular}

In this paper, I investigate Classical Chinese (5thc BC-3rdc AD), viz. the written form of Old Chinese ranging from the end of the Spring and Autumn era (770-476 BC) to the end of the Han dynasty (206 BC-220 AD), covering the Warring States period (475-221 BC). During the Archaic period, the official medium of written expression in China, Classical Chinese (or 文言 wenyan 'Literary Chinese'), was formed. Classical Chinese had functioned as the main written language used in literary texts since the shanggu stage, but its use had progressively diminished from the beginning of the Medieval period during which the current 
spoken Sinitic languages diverged considerably. At the beginning of the 20th century, wenyan was replaced by modern Mandarin as the official Chinese written language (Peyraube 2008).

Classical Chinese (5thc BC-3rdc AD) displays robust syntactic properties, such as object preposing, pronoun fronting to negation and wh-movement, which become rare or even ungrammatical in modern Mandarin. These special syntactic properties of Classical Chinese are worth exploring. Apart from the distinctive linguistic features, the reason why I investigate Classical Chinese also lies in the fact that Chinese language is the 'only one of a very few languages whose history is documented in an unbroken tradition extending back to the second millennium BC' (Norman 1988), owing to the use of a script independent of particular phonetic manifestation and the unity of culture despite periods of political disunity. Therefore, it is important to analyse Classical Chinese, so as to access the rich linguistic data and cultural heritage (Wang et al 2007, Peyraube 2008, Lau 2018). Additionally, compared to modern Mandarin, Classical Chinese is less discussed.

In this historical linguistic research, I explore topical constructions in Classical Chinese, namely, the Chinese language ranging from the 5thc $\mathrm{BC}$ to $3 \mathrm{rdc} \mathrm{AD}$. I collect data from Ancient Chinese corpora using corpus linguistic methodologies and practices such as extraction of corpus data and statistical evaluation. When analysing the data, I follow a hermeneutic interpretive approach; English translations of the Classical Chinese citations are done by myself. As for the discussions and arguments, they are based on a syntactic theoretical framework, in line with previous syntactic literature on modern Mandarin.

Classical Chinese examples in this paper are mainly extracted from three primary sources: 1) the Scripta Sinica electronic database (http://hanchi.ihp.sinica.edu.tw/ihp/hanji.htm), which is one of the largest full text databases encompassing historical materials in Chinese, with 1,318 classics and 737,666,984 characters; 2) the CCL corpus (http://ccl.pku.edu.cn:8080/ccl_corpus/) developed by the Centre for Chinese Linguistics, Peking University, which contains approximately 700 million Chinese Characters ranging from the 11 the $\mathrm{BC}$ to the contemporary era; and 3) the Chinese Text Project (https://ctext.org/), which is an open-access digital library focusing on premodern Chinese text, with more than 30,000 titles and over 5 billion characters. Classical Chinese examples that I have selected from these corpora represent a wide range of writing found in various texts. Examples are extracted from key books exemplified by The Analects, Mencius, Zuo Commentary and The Records of the Grand Historian, which are written by different authors and provide a considerable amount of discourses and genres, including historical narrative, political essay, philosophical prose, ethical writing, ritual record and medical text.

In this research, I investigate non-wh constructions with and without marking functioning as internal and external topics in Classical Chinese, and compare them with topical structures in modern Mandarin. In Section 2, I introduce the distinctive features of Classical Chinese. In Section 3, I present previous literature on topics of modern Mandarin. In Section 4, I discuss fronted pronouns in the context of negation as internal topics in Classical Chinese. In Section 5, I discuss base-generated and moved external topics in Classical Chinese, including their features, coreferential relation and categories. In this paper I focus on non-wh constructions, but I also draw on occasional wh examples as additional supporting evidence.

\section{DISTINCTIVE FEATURES OF CLASSICAL CHINESE}

Chinese has changed considerably from Classical Chinese to contemporary Mandarin. For instance, the overall lexicon of Classical Chinese is different from that of 
contemporary Chinese: although there is a small proportion of words from Ancient Chinese that is still attested in the contemporary language, there are numerous words that have disappeared from the modern language or have adopted disparate meanings (He and Jiang 1980, Peyraube 2008).

Analogous to its modern counterpart, Classical Chinese is an SVO language, but a derived SOV order is also prevalent (Light 1979, Sun and Givón 1985, Peyraube 1994, 1996, 1997, Djamouri 2001, 2005, Aldridge 2010, 2013, 2015, Meisterernst 2010, Djamouri et al 2007, 2012, among many others). In Classical Chinese, when nominal and pronominal DPs function as objects, they can occur in their postverbal base positions, following the canonical V-DP order, as shown in (1) and (2) respectively. In the context of negation, pronominal, but not nominal, DPs may undergo preposing from their postverbal base positions to preverbal landing sites, generating a derived DP-V sequence without the support of any additional marking. Example $(3 \mathrm{a} / \mathrm{b} / \mathrm{c})$ illustrates the fronting of a first, second and third person pronoun respectively. It is worth mentioning that pronoun fronting in the context of negation is a robust feature of Classical Chinese (Wang 1958, Shi 1986, Yu 1989, Wei 1990, Feng 1996, Peyraube 1997, Djamouri 2000, Aldridge 2010, 2015).

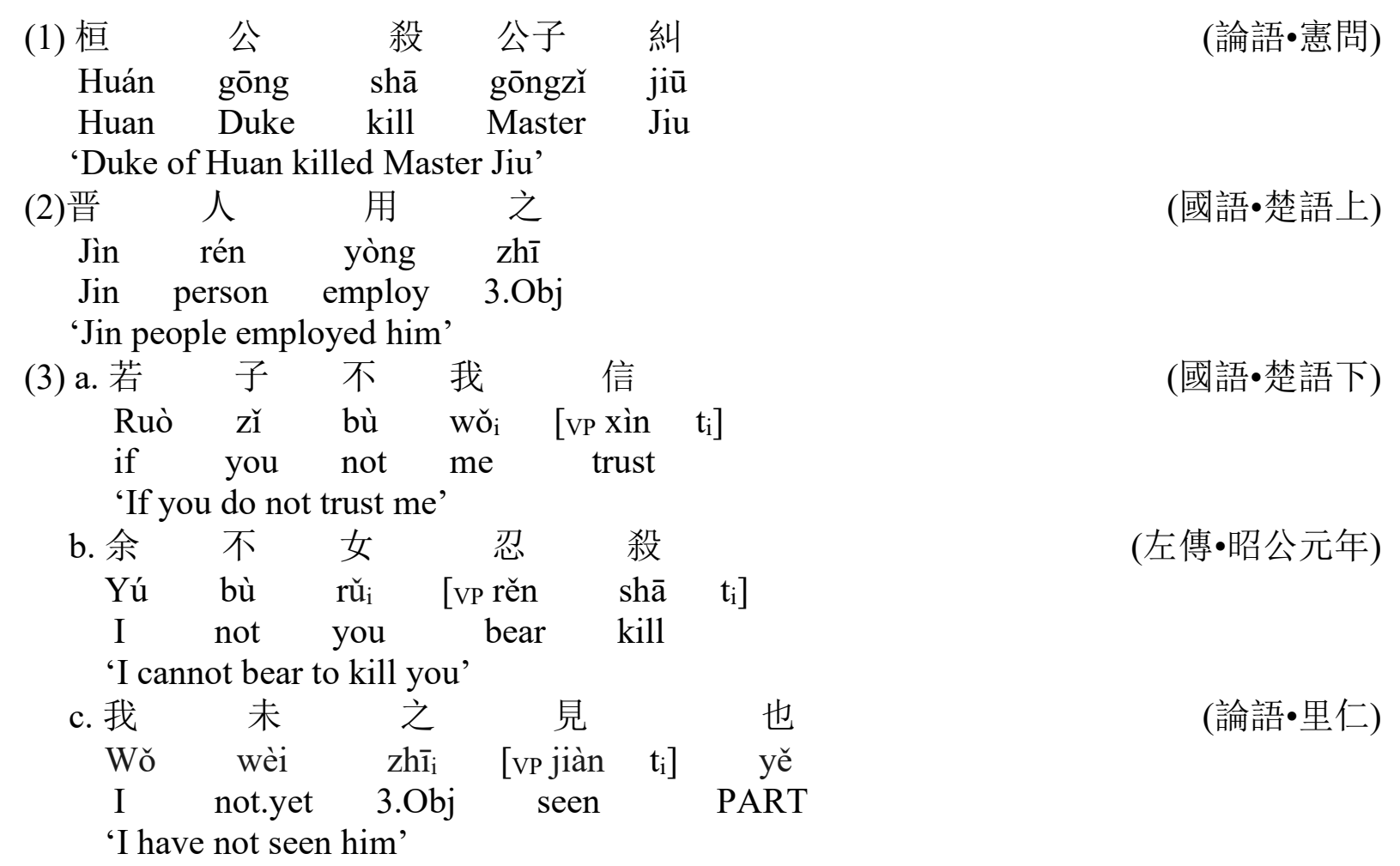

Although zero-marking preposing is restricted to pronominal objects and requires a negative environment, if a morpheme 之 $z h \bar{\imath}$ or 是 $s h{ }^{1}{ }^{1}(4 \mathrm{a}-\mathrm{b} / \mathrm{c})$ is employed to mark the

\footnotetext{
1 之 ZHI and 是 SHI are referred to as contrastive markers in Peyraube (1996) and pretransitive/preverbal markers in Peyraube (1997). It is notable that only ZHI can function as the fronting marker following preposed wh-constituents, yet * wh-SHI is never attested, in that SHI always occurs below negation, yet $w h$ never follows negation due to the Intervention Effect (Wang 2015). Apart from being a fronting marker, the same graph $z h \bar{\imath}$ may also function as a third person accusative pronoun (either animate or inanimate), a resumptive pronoun, a genitive marker, or a marker for explicit subordination (Wang 2013). As for the fronting marker SHI, it can additionally function as a demonstrative or determiner shi 'this', and it may originate from the demonstrative shi through a process of grammaticalisation (Peyraube 1997).
} 
fronting, then fronted DPs can be either nominal or pronominal $(4 \mathrm{a} / \mathrm{b})$, and the context can be either negative or positive $(4 a-b / c)$.

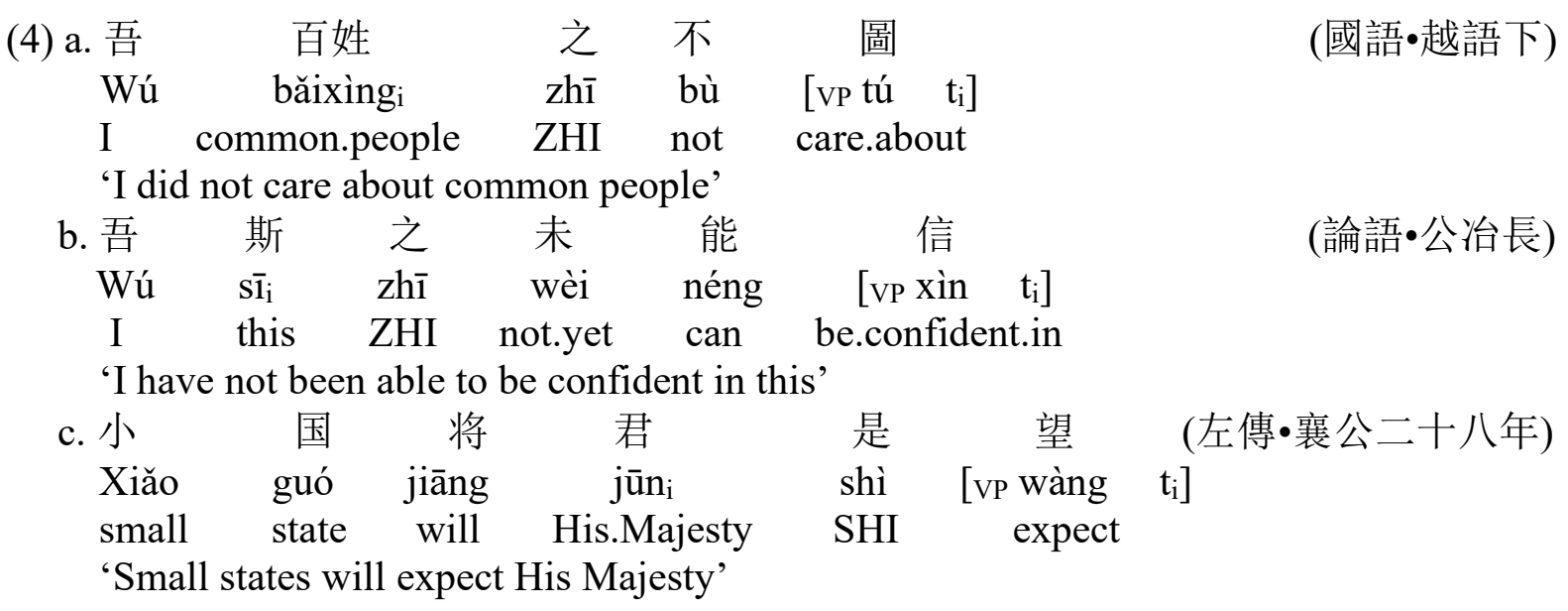

Furthermore, when a preposed nominal/pronominal object is followed by ZHI/SHI, it can be preceded by a morpheme 唯 wéi indicating 'only' (5). I state that 唯 wéi is to introduce foci, parallel to the copula shi in modern Mandarin (Cheung 2008, 2014, Paul and Whitman 2008, Hole 2012).

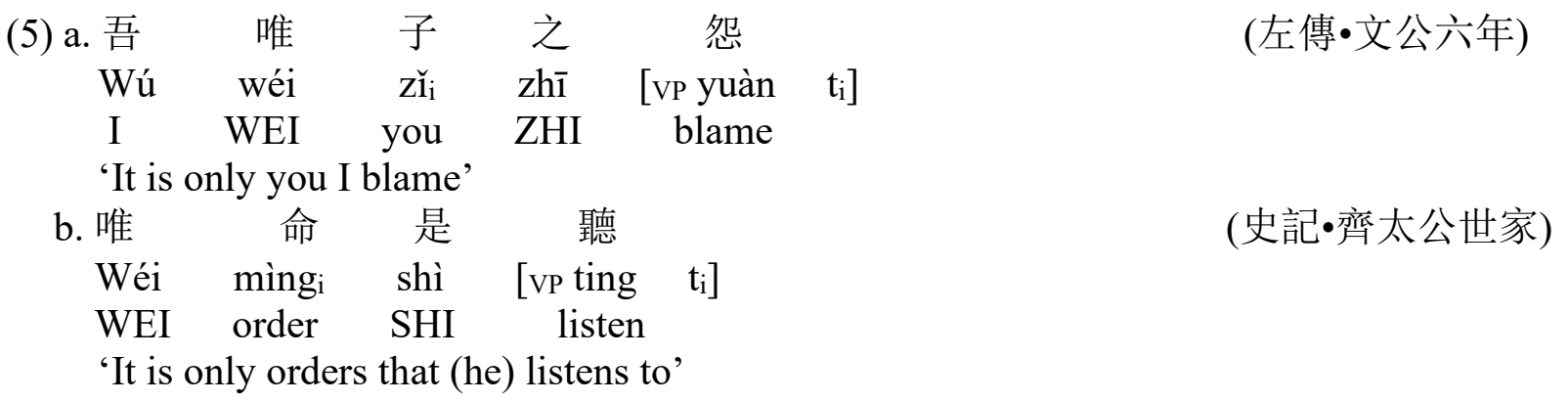

Apart from object preposing, Classical Chinese allows fronting of other noninterrogative constituents such as predicates (6).
(6) 大 哉㖪
Dà $\quad$ zāi kǒngž̀ $t_{i}$
great PART Confucius
'Confucius is great'

\section{TOPICS IN MANDARIN}

As a topic-prominent language (Chao 1968: 69-72, Li and Thompson 1976), modern Mandarin has attracted a significant amount of research interest on its topic-comment constructions for analysis of information-structural categories. According to traditional views, topic in modern Mandarin displays robust distribution and properties: it is definite or generic; it has discourse features; it occupies sentence-initial position of the first clause in a topic chain; it can be separated from the rest of the sentence by particles $a / y a$, ne, me or $b a$; it can extend its semantic domain to more than one clause; it is in control of the pronominalisation or deletion process of all coreferential NPs in a topic chain; except in clauses where it is also subject, it plays no role in such processes as true reflexivisation, Equi-NP deletion and 
imperativisation (Li and Thompson 1976, 1981, Tsao 1978, 1979, 1987, 1990, Li 1990, Jiang 1991, Qu 1994).

Relational definition of topic is ' $[\mathrm{s}, \mathrm{X}[\mathrm{s} \ldots \mathrm{Y} \ldots]]$, where $\mathrm{X}$ is a major category and $\mathrm{Y}$, possibly empty, is related to $\mathrm{X}^{\prime}$ (Xu and Langendoen 1985: 20). Relational givennessnewness concerning the divide between topic and comment entails a partition of the semantic/conceptual representation of a sentence into two complementary parts, including what the sentence is about (the logical/psychological subject) and what is predicated about the other part (the logical/psychological predicate) (Gundel and Fretheim 2006). Based on relational givenness-newness, a topic is defined as the part of the sentence which is structurally marked as what the sentence is about or the frame in which the sentence holds, while a comment is marked as the predicate which holds for the topic (von Prince 2012).

Shi (2000) defines topic based on its structural position, structural relationship with the verb and discourse function. Topic-comment construction is treated as a syntactic device derived from basic sentence structures via syntactic operations, so as to fulfill discourse functions. A topic 'represents an entity that has been mentioned in the previous discourse and is being discussed again in the current sentence, namely, topic is what the current sentence is set up to add new information to' (386). Topic is correlated with a position inside the comment and it depends on an element inside the comment for its thematic role. Given the fact that the thematic role is not independent, topic does not have syntactic function of its own.

A topic can be linked to a gap, a resumptive pronoun or an epithet. The coreferential relation between a topic and a gap inside the comment is subject to locality constraint which is based on the disparity between a gap and a resumptive pronoun coreferential with the topic. Although resumptive pronouns can be employed to replace gaps, they should be avoided whenever possible. However, when topics are related to elements inside islands such as relative and adverbial clauses, resumptive pronouns are obligatory and leaving gaps in the comments would generate infelicitous topic-comment constructions ( $\mathrm{Li}$ and Thompson 1979, Huang 1982, Li 1990, Jiang 1991, Shyu 1995, Shi 2000, Del Gobbo and Badan 2007, Huang et al 2009, Badan and Del Gobbo 2011, Cheung 2014).

Topics in Mandarin can be categorised into two types, viz. base-generated ones and moved ones. Base-generated topics denote Aboutness Topic (AT) structures without a real resumptive element or a pro or a trace in the sentence, and they can be further divided into 'whole-part' ATs and 'possessive' ATs. Moved topics are constituted of Hanging Topic (HT) and Left Dislocation Topic (LD). There are six distinctions between these two kinds of topics. First, HT must be a bare DP, yet LD can be a PP. Second, HT always requires a resumptive pronoun and only agrees with it in number and gender; LD only requires a resumptive pronoun (clitic) when it is correlated with a direct or partitive object, and LD agrees with the clitic in gender, number and Case. Third, HT does not need to agree with the resumptive pronoun inside the predicate in Case, yet LD agrees with the resumptive pronoun in Case. Fourth, HT can be resumed by a tonic pronoun or epithet, yet LD cannot. Fifth, it is permissible to have multiple LDs, but not HPs. Sixth, HT and LD can co-exist and the former always precedes the latter (Benincà and Poletto 2004, Badan and Del Gobbo, 2011).

In modern Mandarin, an object can undergo fronting from its postverbal base position to the 'low IP area' (dubbed by Paul (2005)) between TP and $v \mathrm{P}$, preceding adverbs, negation and auxiliaries. Such object preposing is different from the lián ...yěldōu 'even' construction (7), as it requires no additional marking (8).
(7) a. Tā
lián
wǒ/zhāngsān
yě/dōu
qǐng-le
3SG even 1SG/Zhangsan
also/all invite-PERF

'He invited even me/Zhangsan.' 


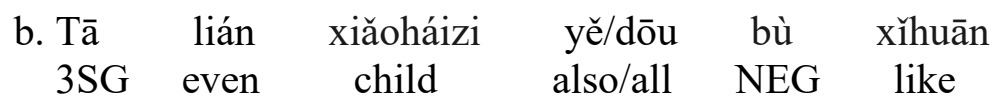

'He doesn't even like children.'

(8) a. Nǐ zhōngyào yĭqián yòng-guò ma?

2SG Chinese.medicine before use-EXP PART

'Have you ever taken Chinese medicine before?'

b. Wǒ diànyǐng bú kàn le

1SG film NEG watch

'I won't go to the movies.'

c. Nǐ kūnqǔ huì bú huì?
2SG Kunqu.opera know NEG know
'Do you know how to sing the Kunqu-opera?'

(From Paul 2002: 698/697)

Object preposing without marking in modern Mandarin is commonly accepted as a case of focalisation in the literature (Ernst and Wang 1995, Shyu 1995, 2001, Zhang 1997, Tsai 2000, among many others). Nevertheless, Paul (2002) invalidates the focalisation account on both syntactic and semantic grounds, and postulates that object preposing in Mandarin are internal topics between the subject and $v \mathrm{P}$, occupying the specifier position of a functional projection. Parallel to external topics, internal objects can be derived either via movement or base-generation; disparate from external topics, internal topics cannot be clauses, and multiple topics are prohibited from the internal topic position.

\section{INTERNAL TOPICS IN CLASSICAL CHINESE}

There are two types of topics in Classical Chinese, namely internal topics in low IP area, as well as external topics in the CP area. In this section, I discuss internal topics.

In line with Paul's (2002) proposal on modern Mandarin, I suggest that preposed non-wh objects in Classical Chinese are also internal topics, parallel to their modern counterparts. Since object preposing in Classical Chinese takes the form of pronoun fronting to negation, preposed pronouns in the context of negation are internal topics.

\section{Pronoun Fronting to Negation in Classical Chinese vs. Object Preposing in Mandarin}

There is no denying the fact that object preposing in modern Mandarin and that in Classical Chinese are not completely consistent.

First, object preposing in standard Mandarin (but not in some dialects) forbids pronouns (Hou 1979, Paul 2002), whereas that in Classical Chinese are restricted to pronouns (9), and preposing of nominal DPs without any accompanying marker is not attested in corpora.

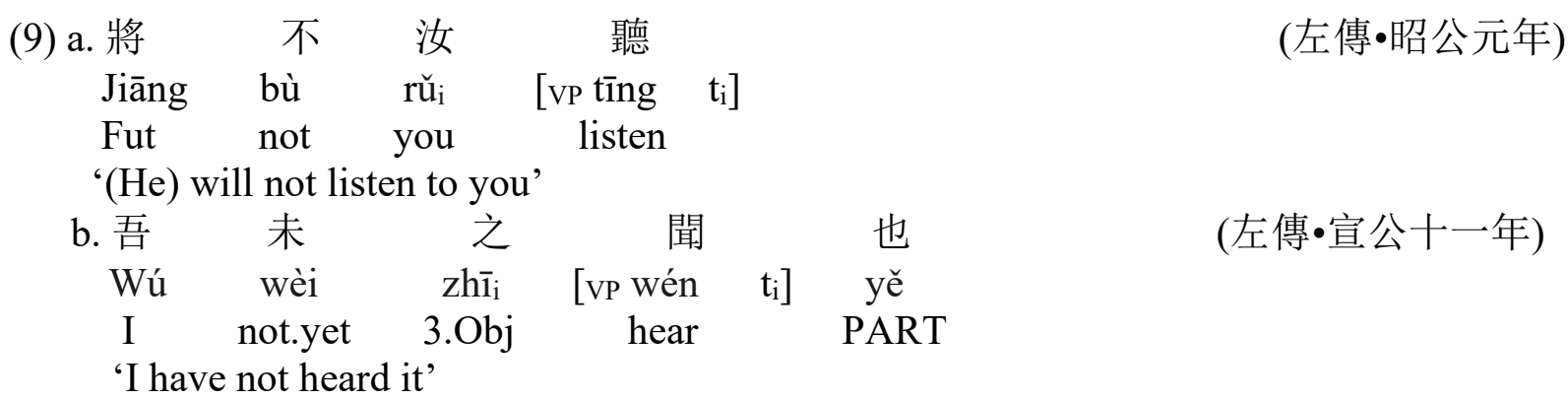




$\begin{array}{lcccc}\text { c. 未 } & \text { 之 } & \text { 能 } & \text { 行 } \\ \text { Wèi } & \mathrm{zh}_{\mathrm{i}} & \text { néng } & \text { [vp xíng } & \mathrm{t}_{\mathrm{i}} \text { ] } \\ \text { not.yet } & 3 . \mathrm{Obj} & \text { can } & \text { execute } & \\ \text { '(He) has not executed it' } & & \end{array}$

Second, object preposing in modern Mandarin takes place in both positive and negative contexts (cf. (8a) and (8b)), whereas that in Classical Chinese only occurs in a negative context (see (9)).

Third, preposed objects in Mandarin target a landing site to the left of adverbs, negation and auxiliaries (Paul 2002), whereas those in Classical Chinese intervene between adverbials/negators and auxiliaries. Evidence demonstrates that pronouns base-generated postverbally move to a position following an aspecto-temporal adverb 將 jiāng and negators 不 bù or 未 wèi (9a-b) and preceding an auxiliary 能 néng. That is to say, the relative order between preposed objects and medial elements in Mandarin is $\mathrm{Obj}>\mathrm{Adv} / \mathrm{Neg} / \mathrm{Aux}>\mathrm{V}$, yet that in Classical Chinese is $\mathrm{Adv}>\mathrm{Neg}>\mathrm{Obj}>\mathrm{Aux}>\mathrm{V}$.

Despite the discrepancies, object preposing in modern Mandarin and that in Classical Chinese share three common properties.

First, both object preposing in Classical Chinese and that in modern Mandarin are derived from movement, rather than base-generation. As mentioned previously, the canonical order for both Classical Chinese and modern Mandarin is SVO, and the reverse SOV order is derived from movement from postverbal base positions to preverbal landing sites.

Second, neither preposed nominal/prenominal objects in Mandarin nor preposed pronominal DPs in Classical Chinese requires any marking. Pronouns in (9) and (10) (see below), for instance, undergo movement to a position following negation, and no marker is attached to them.

Third, analogous to modern Mandarin, Classical Chinese allows a preposed DP to be either [+human] or not, as exemplified by a third person accusative pronoun 之 $z h \bar{\imath}$ in $(10 \mathrm{a} / \mathrm{b}-$ c).

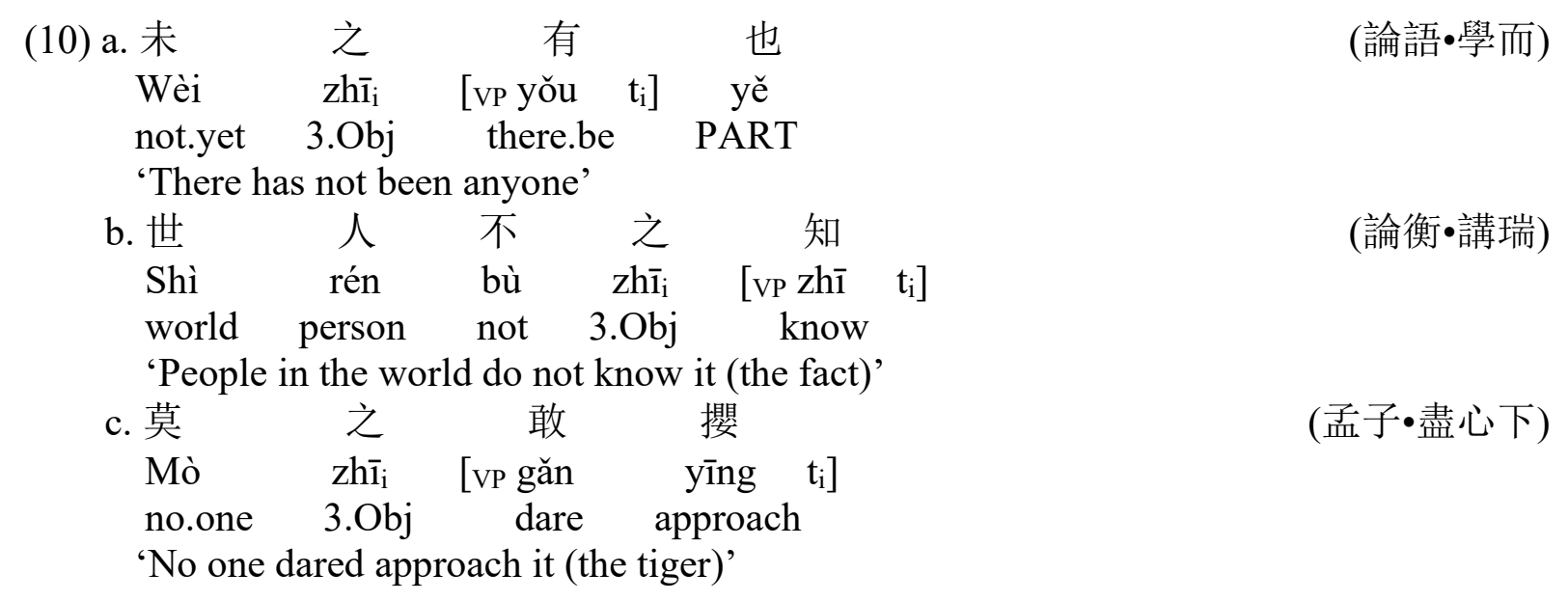

\section{Pronoun Fronting to Negation vs. ZHI/SHI Focus}

In Classical Chinese, two types of SOV constructions need to be distinguished, i.e. pronoun fronting in the context of negation, and focus constructions marked by ZHI/SHI. The discrepancies between these two kinds of constructions lend support to the topical nature of pronoun fronting to negation. 
First, pronoun fronting to negation and focus marked by ZHI/SHI permit distinct types of preposed elements. As is obvious from the term, pronoun fronting to negation denotes pronominal DPs exclusively. Focus marked by ZHI/SHI, however, is not restricted to pronominal DPs (see (14) below). ZHI/SHI focus also allows nominal DPs, clauses and whitems.

Example (11a) and (11b) indicate that morphemes 之 $z h \bar{\imath}$ and 是 shì can follow nonwh nominal objects to mark their preverbal movement.

(11) a. 吾

\begin{tabular}{lcccc} 
吾 & 百姓 & 之 & 不 & \multicolumn{1}{c}{ 圖 } \\
Wú & băixìng & zhī & bù & [vp tú \\
$\mathrm{t}_{\mathrm{i}}$ ] \\
I & common.people & ZHI & not & care.about \\
'I did not care about common people' & &
\end{tabular}

(國語•越語下)

\begin{tabular}{|c|c|c|c|c|}
\hline b. 將 & 禍 & 是 & 務 & 去 \\
\hline Jiāng & huò̀i & shì & wù & [vp qù $\left.\mathrm{t}_{\mathrm{i}}\right]$ \\
\hline Fut & misfortune & SHI & endeavor & dispel \\
\hline
\end{tabular}

Examples in (12) show that clausal objects can be found in foci marked by ZHI/SHI, yet no data involving zero-marking contain any clausal objects.
(12) a. 君 今 非王室 不 平安 是 憂 Jūn jīn fề [wángshì bù píng'ān $]_{i}$ shì [vp yōu $\left.\mathrm{t}_{\mathrm{i}}\right]$ Your.Majesty now not royal.family not peaceful SHI worry 'Now what Your Majesty worries about is not that the royal family is not peaceful'

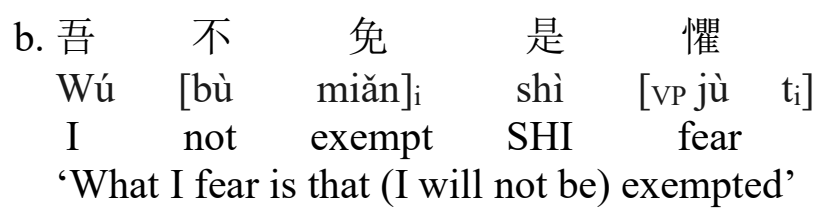
(國語・吳語)

Examples in (13) exemplify focus ZHI/SHI with wh-phrases.
(13) a. 宋何罪之有？ (墨子・公輸)
Sòng [hé zuì $]_{i}$ zhī [vp yǒu $\left.t_{i}\right]$ ?
Song what sin ZHI have

'What sin does Song have?'

b. 宋何役之不會，而何盟之不同?

Sòng [hé yì $]_{\mathrm{i}}$ zhī bú [vp huì $\mathrm{t}_{\mathrm{i}}$ ], ér [hé méng] $]_{\mathrm{j}}$ zhī bù [vp tóng $\mathrm{t}_{\mathrm{j}}$ ]? Song what battle ZHI not enter Conj what alliance ZHI not join 'What battle does Song not enter, and what alliance does (it) not join?'

(左傳・昭公二十五年)

Second, pronoun fronting to negation and focus marked by ZHI/SHI display disparate relative orders with negation. To be more specific, when a pronoun raises independently, it always targets a position between negation and $v \mathrm{P}$, as shown in (9-10). However, if a DP undergoes preposing accompanied by a marker ZHI/SHI, its landing site is above negation, as in $(14 a)(=(4 b))$ and $(14 b)$. That is to say, there exists a hierarchy among preposed items, markers and negators in the medial domain, viz. DP $>\mathrm{ZHI} / \mathrm{SHI}>\mathrm{Neg}>$ Pron. 
Note that as can be seen from (14b), apart from its functional use as a fronting marker, the morpheme 是 shi can also function as a demonstrative pronoun.

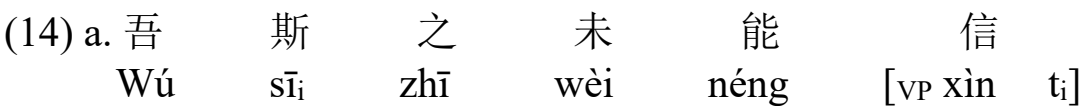
I this ZHI not.yet can be.confident.in
'I have not been able to be confident in this'
b. 是之不之務
Shì̀ zhī bú [vp wù $\left.\mathrm{t}_{\mathrm{i}}\right]$
this ZHI not conduct
'(If you) do not conduct this'
(論語•公治長)

Third, constructions marked by ZHI/SHI are compatible with an 'even' focus interpretation, whereas pronoun fronting to negation is not. Under an 'even' circumstance, the speaker can presuppose that there are other elements sharing the same feature as that attributed to the quantified elements (Paris 1998). In (15a), based on a following rhetorical question and contextual information, the former clause should be assumed to imply an 'even' interpretation for the element being quantified that the person does not even adore his own parents, not to mention others. A similar interpretation is available in (15b) as well.

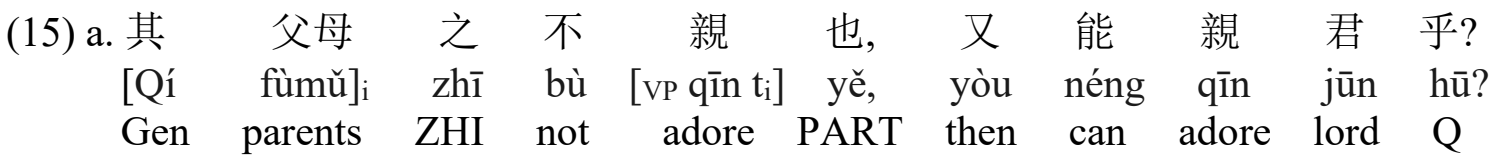

'(He) does not adore his parents, then how can (he) adore the lord?'

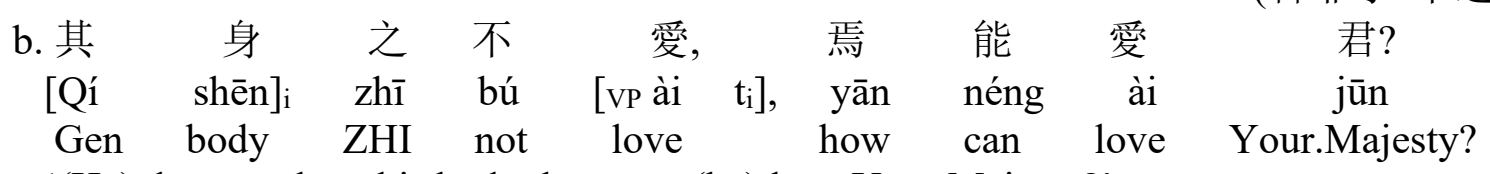

'(He) does not love his body; how can (he) love Your Majesty?'

(管子・戒)

\section{Pronoun Fronting to Negation vs. Cleft}

In Classical Chinese, when a preposed DP is marked by ZHI/SHI, the construction can be preceded by a morpheme 唯 wéi indicating assertive modality and frequently translated as 'only' (Djamouri 2001) to form a cleft structure WEI...ZHI/SHI. Cleft contractions exhibit exhaustiveness and bipartition, yet neither phenomenon exists in pronoun fronting in negation.

First, exhaustiveness is absent from constructions involving pronoun fronting to negation, whereas it is present in WEI...ZHI/SHI clefts. Exhaustiveness specifies an exhaustive set for which a given proposition holds true, excluding all other possibilities (É. Kiss 1998, Cheung 2014). In (16a), exclusiveness is expressed, in that 唯 WEI 'only' excludes the DP 'mansion' in the former clause, rendering the clefted DP 'neighbour' the only available option. Moreover, the former clause indicates that the property of being chosen denoted by the presupposition is not held by the DP 'mansion' that is negated by a negator 非 $f e ̂ i$. The former clause in (16b) that involves pronoun fronting to negation, however, does not impose exhaustivity, and the following clause confirms that an alternative is true.
(16) a. 非
宅是
葍,
唯
鄰
是葍 
Fèi zhái $i_{i}$ shì $[\mathrm{vp} \text { bǔ }]_{\mathrm{i}}$, wéi $\operatorname{lín}_{\mathrm{j}}$ shì $\quad[\mathrm{vp} \text { bǔ }]_{\mathrm{j}}$ not mansion SHI choose WEI neighbour SHI choose

'It is not mansions (people) choose; it is only neighbours (people) choose'

b. 吾未之學 也; 雖然, 吾 嘗 聞之矣

Wú wèi ${ }_{i}$ zhī [vp xué $\mathrm{t}_{\mathrm{i}}$ ] yě; suīrán, wú cháng wén zhī yǐ

I not.yet 3.Obj study PART Conj I before hear 3.Obj PART

'I have not studied it; but I heard it before'

$$
\text { (孟子・滕文公上) }
$$

Second, bipartition into focus and presupposition is absent from constructions involving pronoun fronting to negation, whereas it is present in constructions involving clefts. This asymmetry concerning bipartition is reflected by the fact that whole VPs in sentences involving pronoun fronting to negation can be negated/questioned, yet negation and interrogation do not apply to entire VPs in sentences involving WEI...ZHI/SHI. In $(17 \mathrm{a} / \mathrm{b})$ that involves a raised pronoun, it is not only the pronoun that is negated/questioned; the verb is negated/questioned as well. Nevertheless, in (18), bipartition excludes the presupposition from the scope of negation/interrogation, and only the raised DP is affected. As for another property implied by bipartition, i.e. listing, the reason why it is not realised in WEI...ZHI/SHI structures is due to this cleft per se: WEI expresses an 'only' interpretation that is incompatible with list contexts.

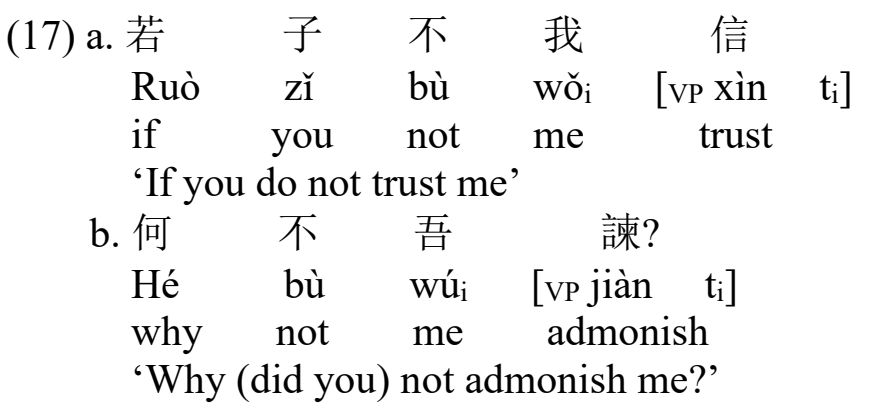

(國語・楚語下)

(18)小国将君是望, 敢不唯命是鳣?

Xiăo guó jiāng jūn $n_{i}$ shì [vp wàng $\mathrm{t}_{\mathrm{i}}$ ], găn bù wéi mìng shì [vp ting $\mathrm{t}_{\mathrm{j}}$ ]? small state will His.Majesty SHI expect dare not WEI order SHI listen

'Small states will expect His Majesty; how dare (they) not listen to orders only?'

(左傳・襄公二十八年)

To summarise, fronted pronouns in the context of negation in Classical Chinese function as internal topics, similar to preposed objects in modern Mandarin, in that they both have zero marking and optional [+human] feature, and they are both derived from movement. In addition to the topical properties it demonstrates, pronoun fronting to negation also displays properties that are inconsistent with foci, including ZHI/SHI focus and WEI...ZHI/SHI cleft. For one thing, pronoun fronting to negation is disparate from ZHI/SHI focus, because they permit distinct preposed elements and display different relative orders with negation, and only the latter can adopt an 'even' interpretation. For another, pronoun fronting to negation is dissimilar to WEI...ZHI/SHI cleft, in that the latter, but not the former, exhibits exhaustiveness and bipartition. 


\section{EXTERNAL TOPICS}

In Classical Chinese, a fronted pronoun can target a landing site between negation and $\nu \mathrm{P}$ in the low IP area, functioning as an internal topic. When a preposed object or predicate raises to a position above subject in the left periphery, it functions as an external topic. Additionally, external topics can be base-generated. That is to say, in Classical Chinese, internal topics are restricted to moved ones, whereas external topics can be moved ones and base-generated ones.

\section{Topical Features}

In Classical Chinese, objects and predicates can undergo movement from their base positions to a sentence-initial position in the CP domain.

As mentioned previously, objects are base-generated postverbally in this SVO language. Apart from staying in situ, objects have an option to raise to the left periphery ccommanding the subject. Preposed objects can be either DPs or TPs, as in (19a) and (19b) respectively.

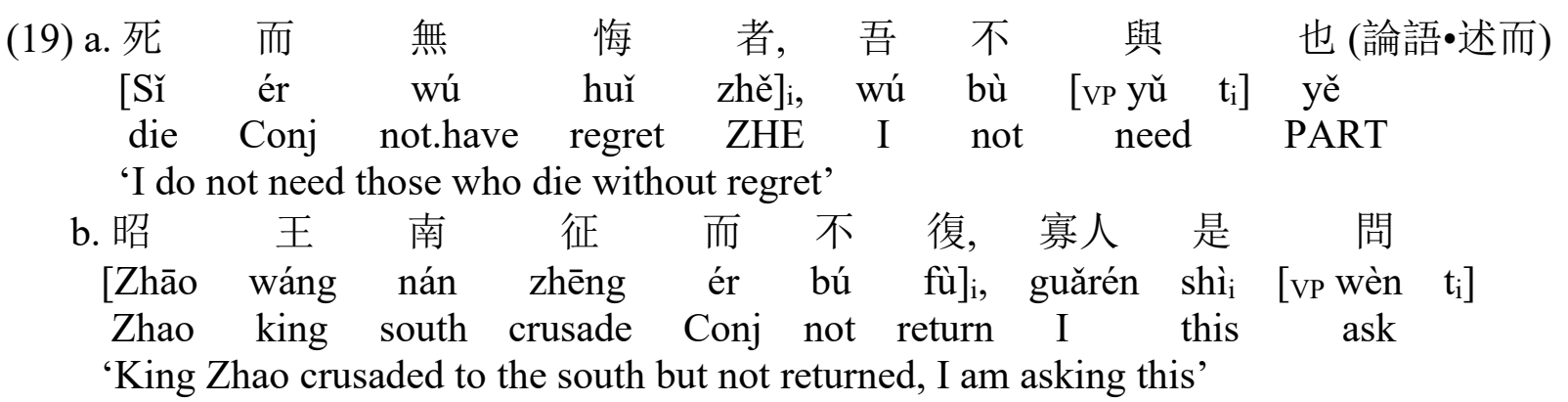

In terms of predicates, they are base-generated following the subject in the sentenceinternal domain. The canonical position of predicates is in (20) which also shows that a copula intervening between the subject and the predicate is optional. Apart from staying in situ, predicates can undergo optional movement from its base position following the subject to the $\mathrm{CP}$ area, and the preposed predicates display features of external topics.
(20) a. 是 爲賊
Shì wéi zéi
this be vermin
'This is vermin'
b. 篤 志而體, 君子 也

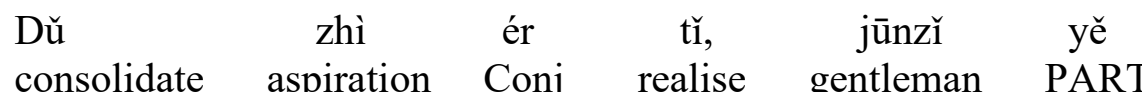
'(Those who) consolidate and realise aspiration are gentlemen'
(論語・憲問)

Before discussing the topical properties of predicates moved to a sentence-initial position, I would like to present the types of preposed predicates. Different from fronted objects that are restricted to DPs, fronted predicates allow DPs and AdjPs, both of which can land in the CP domain preceding the subject. (21a/b) illustrates the movement of a nonwh/wh DP predicate from its base position below a subject to its landing site above the subject, ending up in the CP area. Examples in (21c-d) contain AdjPs. 

(21) a. 君子 哉若
人
(論語•公冶長)
Jūnž̌
gentleman PART Det person
'This person is a gentleman'

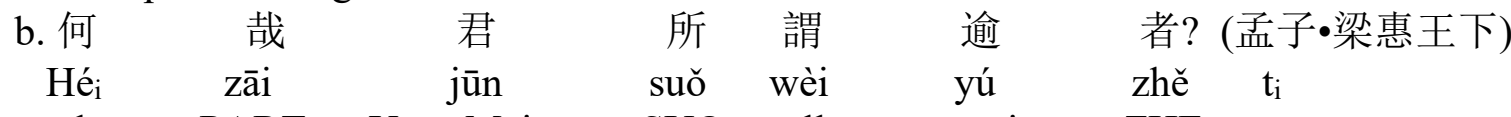
what PART Your.Majesty SUO call arrogation ZHE
'What is the arrogation that Your Majesty call?'
c. 賢哉回等
Xián $_{\mathrm{i}} \quad$ zāi huí $\mathrm{t}_{\mathrm{i}}$ yě
virtuous PART Hui PART
'Hui is virtuous'

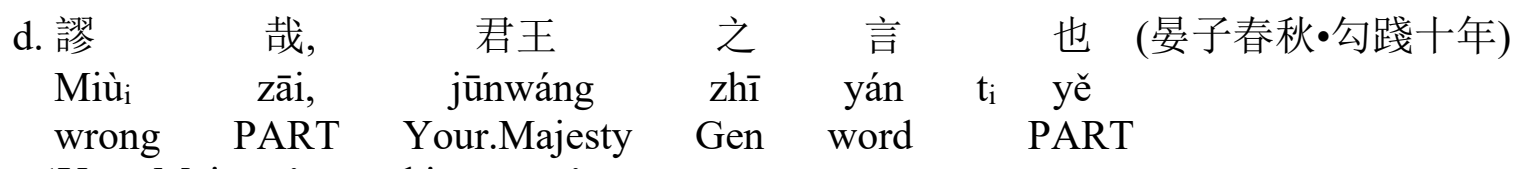
'Your Majesty's word is wrong'

Furthermore, in Classical Chinese there are base-generated items in the CP domain, which have no gap or resumptive pronoun they can be coreferential with in the sentence, as in (22).

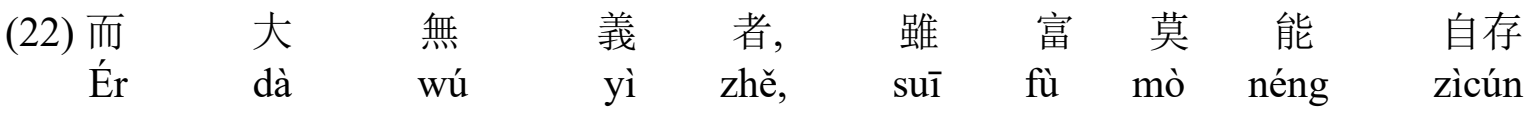
Conj powerful not.have virtue ZHE although rich no.one can self-protect 'While those who are powerful yet have no virtue, although being rich, no one can selfprotect'

(春秋繁露・身之養重於義)

Coming to the topic-like features of moved and base-generated phrases in the $\mathrm{CP}$ domain, the first feature is that the DPs are always definite or generic, and data with indefinite DPs in the left periphery are not attested in corpora. This observation applies to both preposed and base-generated DPs. (23a) and (23b) exemplify definite and generic DPs base-generated in the sentence-initial position. (24a-b) and (24c) exemplify fronted definite and generic DPs functioning as objects. As for the raised predicate DPs 君子jūnž̌ (21a) and 小人 xiăorén (25), they denote a pair of antonymous Confucian concepts representing ideal men and their opposite in general. So despite their translation, these DPs are regarded as being generic.

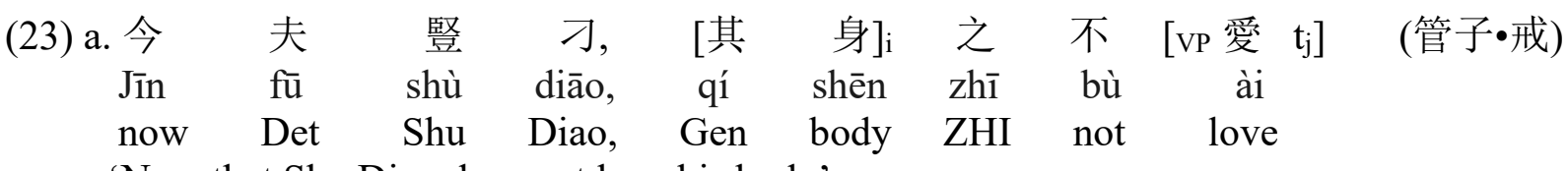
'Now that Shu Diao does not love his body'

b. 今 之 君子, 胡莫 之 行 也子家語・問禮)

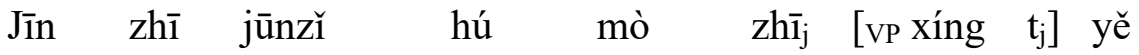

now Gen gentleman why no.one 3.Obj conduct Q

'Gentlemen nowadays, why does no one conduct it?'

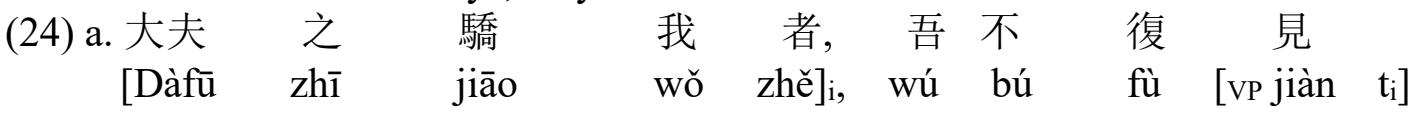


official ZHI discriminate me ZHE I not again see

'I do not see those officials who discriminate against me again'

(左傳・襄公三十一年)

$\begin{array}{lcrrrrr}\text { b. 子路, } & \text { 人 } & \text { 告 } & \text { 之 } & \text { 以 } & \text { 有 } & \text { 過 } \\ \text { Zilùi, } & \text { rén } & \text { [vP gào } & \text { zhīi } & \text { y̌r } & \text { yǒu } & \text { guò } \\ \text { Zilu } & \text { person } & \text { tell } & \text { 3.Obj } & \text { YI } & \text { have } & \text { mistake }\end{array}$

(孟子・公孫丑上)

'Zilu, someone told him of having a mistake' Yùi, wú wèi zh̄̄i $\quad$ [vp xué $\left.\mathrm{t}_{\mathrm{i}}\right]$ yě driving.chariot I not.yet 3.Obj learn PART

'Driving a chariot, I have not learned it'

[Xiăorén $]_{\mathrm{i}}$

despicable.person PART Fan $\mathrm{Xu}$ PART

'Fan $\mathrm{Xu}$ is a despicable person'

The other property justifying the claimed topical nature of preposed objects and predicates is the existence of particles. After objects and predicates move to a sentence-initial position in the CP area, they can be marked by an optional particle, and thus being separated from the comment. As can be observed from (23-24), particles are not obligatory. Examples in (21) and (25) illustrate that a possible particle could be 哉 $z \bar{a} i$. Additionally, 也yě and 乎 $h \bar{u}$ may also be employed to mark fronted elements, as in $(26 \mathrm{a} / \mathrm{b})$.

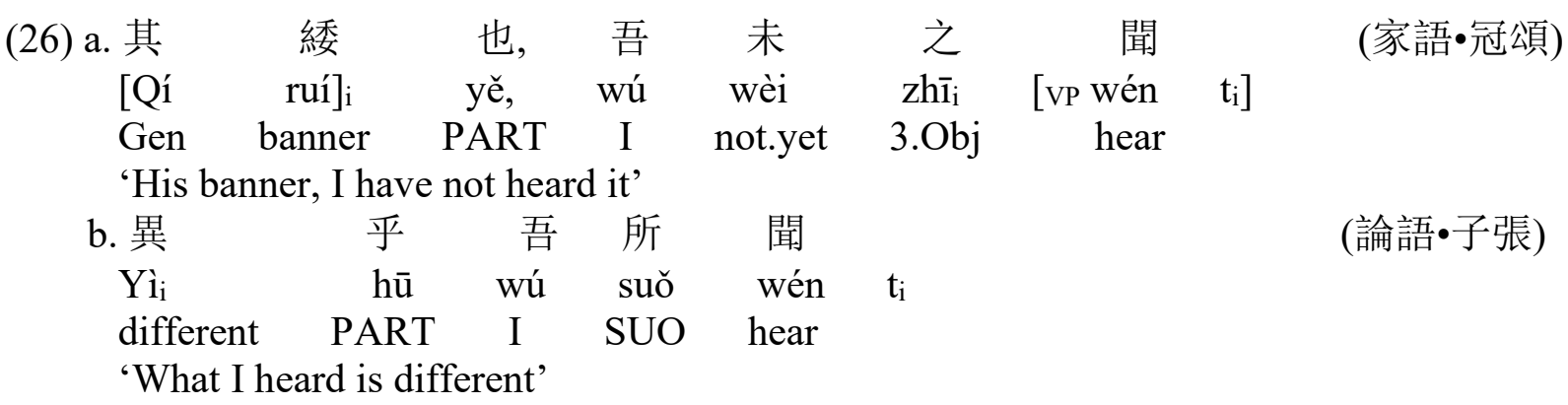

\section{Coreferentiality}

In Classical Chinese, a base-generated external topic is not related to any position in the rest of the sentence, because there is no gap or resumptive pronoun that is linked to this topic. A preposed object/predicate functioning as an external topic, however, can be linked to a gap or a resumptive pronoun inside the comment, and the coreferential relation between the topic and the gap/pronoun is subject to locality constraints.

When a DP is base-generated in the CP area as a topic, it does not link to a gap or resumptive pronoun within the comment. In $(27 a),(=(23 a))$, the DP in the sentence-initial position is base-generated in the left periphery, yet it is not related to any element in the medial domain, or even subcategorised by the verb. It is notable that within the comment, a DP undergoes preposing from a postverbal base position to a position above negation and it is followed by a marker ZHI, so it should be regarded as a focus construction. As for (27b), the sentence-initial DP in the CP domain is also a base-generated external topic, and the topic is not linked with any gap or resumptive pronoun. Similar to $(27 \mathrm{a}),(27 \mathrm{~b})$ also contains a fronted object DP, but this DP is a pronoun fronted to negation without marking, so it is an internal 
object. That is to say, (27a) involves an external topic and a (internal) focus, whereas (27b) contains an external topic and an internal topic.

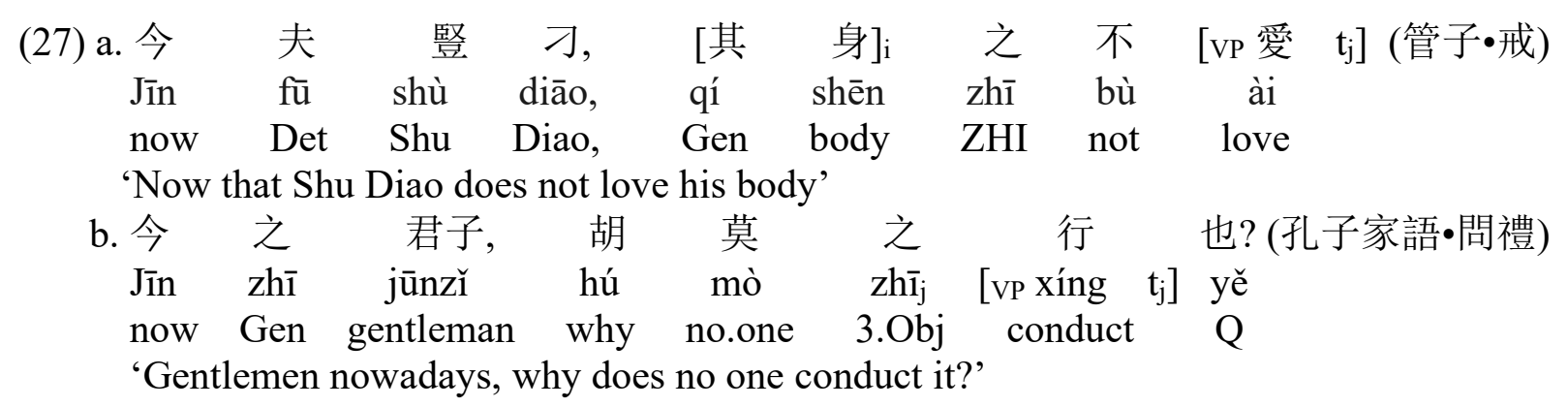

When a DP/TP object moves from its postverbal base position to the $\mathrm{CP}$ area, this external topic can be linked to a resumptive pronoun in the medial domain. Example (28a) $(=(24 \mathrm{c}))$ contains a DP external topic base-generated postverbally as an object, and its coreferential resumptive pronoun additionally becomes an internal topic: in the context of negation, the pronoun undergoes movement from its postverbal base position to a position between the negator and the verb in the low IP area. In (28b), an object fronts to a sentenceinitial position and acts as an external topic, and its related resumptive pronoun inside the comment also undergoes movement. However, different from (28a) which involves pronoun fronting to negation, viz. an internal topic, $(28 \mathrm{~b})$ contains a preposed DP followed by a marker ZHI, which I assume is a focus. As for $(28 \mathrm{c})(=(19 \mathrm{~b}))$, it exemplifies a preposed TP object corresponding to a resumptive pronoun inside the comment. As can be observed from examples that have been presented so far (and those below), the third person accusative pronoun 之 $z h \bar{l}$ is the most frequently attested resumptive pronoun, and the demonstrative pronoun 是 shi as in (28b-c) is less common.

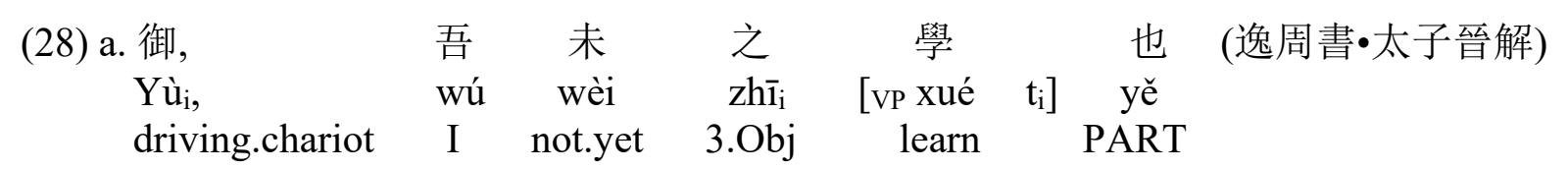

'Driving a chariot, I have not learned it'

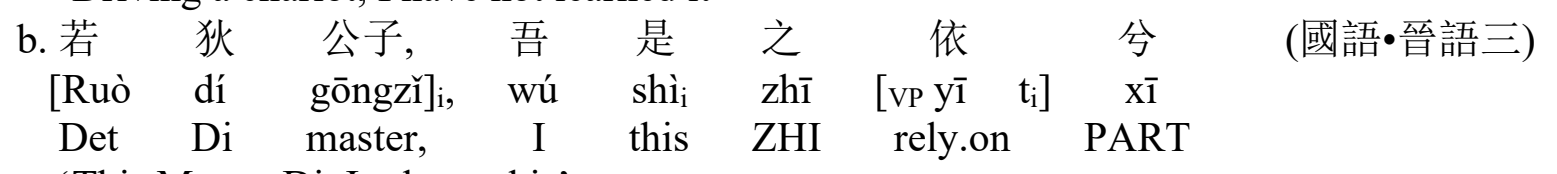

'This Master Di, I rely on this'

$\begin{array}{ccccccccccc}\text { c. 昭 } & \text { 王 } & \text { 南 } & \text { 征 } & \text { 而 } & \text { 不 } & \text { 復, } & \text { 寡人 } & \text { 是 } & \text { 問 } & \\ \text { [Zhāo } & \text { wáng } & \text { nán } & \text { zhēng } & \text { ér } & \text { bú } & \text { fù] } & \text { guărén } & \text { shì̀ } & \text { [vP wèn } & t_{i} \text { ] }\end{array}$

'King Zhao crusaded to the south but not returned, I am asking this'

Alternatively, the topic-related resumptive pronoun can be null, leaving a gap inside the comment. Whenever a resumptive pronoun is replaced by a gap, the topic-related item is never within an island. (29a-b) and (29c) exemplify object and predicate DPs respectively, and none of them is base-generated in an island, so they can be linked to a gap, rather than a compulsory resumptive pronoun.

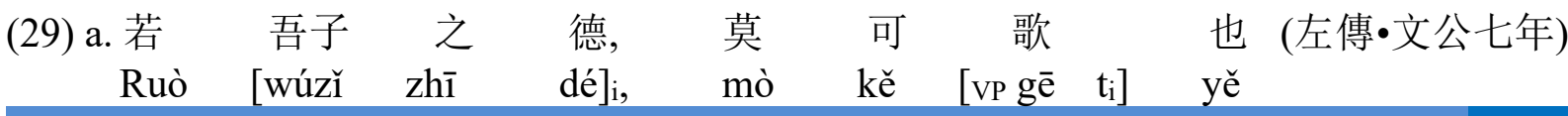


if you Gen virtue no.one can eulogise PART

'If no one can eulogise your virtue'

b. 大夫 之 驕 我者, 吾 不 復 見

[Dàfū zhī jiāo wǒ zhě $]_{i}$, wú bú fù [vp jiàn $\left.\mathrm{t}_{\mathrm{i}}\right]$

official ZHI discriminate me ZHE I not again see

'I do not see those officials who discriminate against me again'

c. 君子 哉鿪伯玉

Jūnž̌i zāi qú bóyù $t_{i}$

(左傳・襄公三十一年)

(論語・衛靈公)

gentleman PART Qu Boyu

'Qu Boyu is a gentleman'

Nonetheless, a resumptive pronoun is obligatory when the topic is coreferential with an element inside an island. In (30), the object DP 'sage' moves out of an island caused by coordination, so there is an overt resumptive pronoun linked to this topic. Data concerning DP movement out of islands without resumptive pronouns is never attested in corpora.

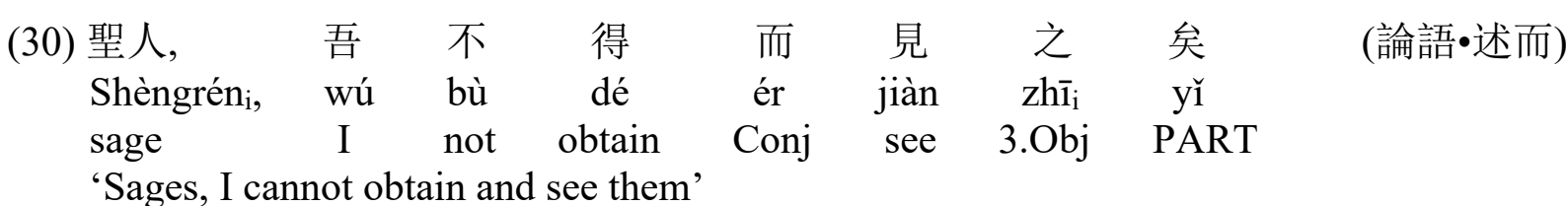

Therefore, I posit that the coreferential relationship between an external topic realised by a preposed object/predicate and its resumptive pronoun is subject to locality constraints.

\section{Base-Generated Topics vs. Moved Topics}

In Classical Chinese, external topics can be categorised into two groups, namely, base-generated topics and moved topics. The former denotes AT, while the latter is constituted of HT and LD.

As discussed previously, there are DPs base-generated in the CP domain and they display no syntactic connection with the rest of the sentence, as shown in $(31)(=(27))$. These base-generated topics are ATs that can be further divided into 'possessive' and 'whole-part' ATs. (31a) describes a 'possessive' relationship between the person as an AT and his body as a resumptive element. By contrast, (31b) expresses a 'whole-part' relation between the topic and its resumptive element in the comment, in that they denote the same cohort.

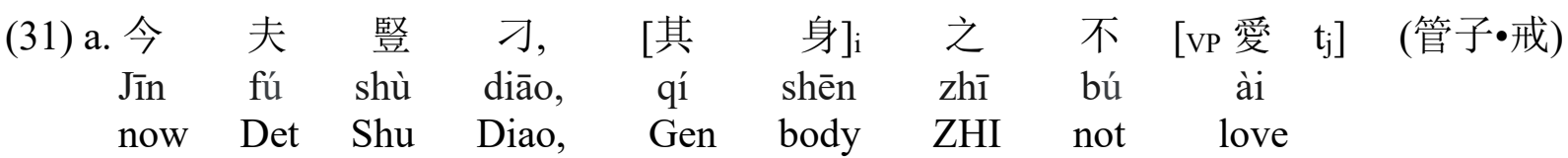
'Now that Shu Diao does not love his body'

b. 今 之 君子, 胡莫 之 行 也家語・問禮) Jīn zhī jūnzǐ hú mò zhīj [vP xíng $\left.t_{j}\right]$ yě

now Gen gentleman why no.one 3.Obj conduct Q

'Gentlemen nowadays, why does no one conduct it?'

In terms of moved topics, they can be further divided into HTs and LDs. Both types of topics entail movement from the low IP area to the CP domain, as well as a related gap/resumptive pronoun inside the comment. 
HTs in Classical Chinese display three properties: 1) they can only be DPs; 2) they require obligatory resumptive pronouns; and 3) they do not agree with resumptive pronouns in Case. As can be observed from examples that have been presented so far, there are preposed DPs in CP area linked to resumptive pronouns in the low IP area, and I state that these moved DPs are HTs, as in, for instance, (28) and (30). In respect of agreement, examples in (32) show that although fronted DPs in the sentence-initial position are coreferential with resumptive pronouns in the comment, they do not agree with each other in Case.

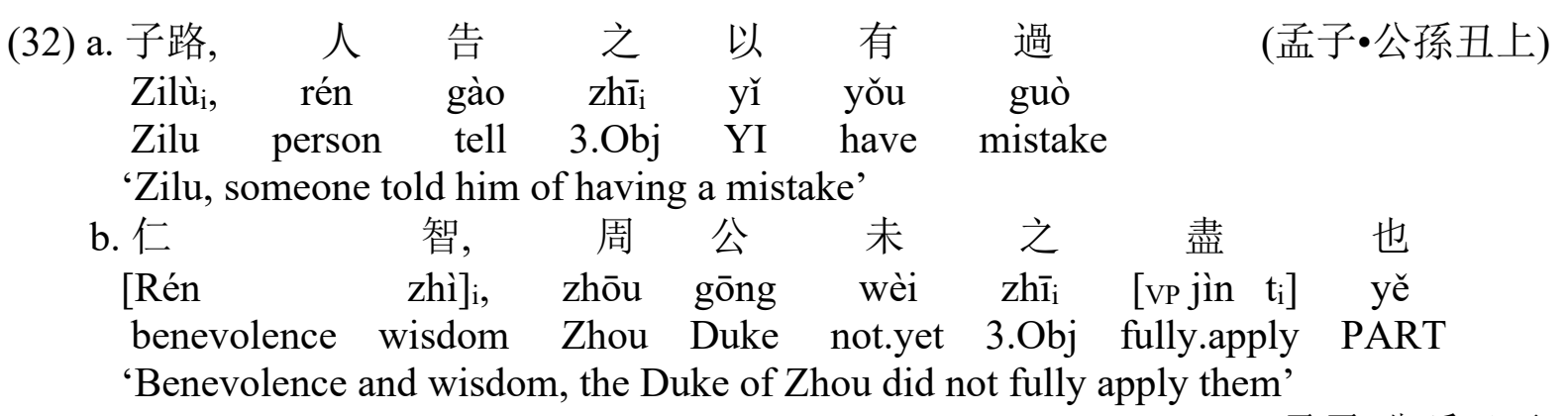

(孟子・公孫丑下)

It should be pointed out that HTs in modern Mandarin agree with their coreferential resumptive pronouns in number and gender (Badan and Del Gobbo 2011), so it seems (32b) serves as an example indicating that HTs in Classical Chinese are distinct from their modern counterparts. There is no denying the fact that the DP in (32b) is constituted of two coordinated parts, yet the accusative pronoun 之 $z h \bar{\imath}$ appears to be singular, so there seems to be a mismatch in number between the topic and its resumptive pronoun. Nevertheless, when the morpheme 之 $z h \bar{\imath}$ functions as a third person accusative pronoun in Classical Chinese, there is lack of morphological progress to mark singularity or plurality. Moreover, 之 $z h \bar{\imath}$ as a third person pronoun does not apply morphological change to distinguish genders. For instance, since the topic DP in (32a) is [+masculine], as its resumptive pronoun, $z h \bar{\imath}$ is presumed to be 'him'; in (33), however, $z h \bar{l}$ is employed to refer to a person of a [-masculine] feature. Besides, the same morpheme may function as a marker ZHI, as in (31a). The lack of morphological conversion concerning singularity/plurality, masculinity/femininity and even word class applies to the less common resumptive pronoun 是 shi as well, because the same morpheme shi can freely function as a singular/plural/masculine/feminine demonstrative pronoun, fronting marker (18) or determiner (33b). As a consequence, the interpretation of pronouns $z h \bar{\imath}$ and shi entirely depends on contextual information. Therefore, $(32 \mathrm{~b})$ does not jeopardise the claimed parallel between HTs in Classical Chinese and those in modern Mandarin.

(33) a. 齊 侯 與 蔡 姬 乘 舟 于 直... 公 怒, 歸 之 Qí hóu yǔ cài jī chéng zhōu yú yòu ...gōng nù, gū̄ zhī Qi Duke Conj Cai Concubine take boat at park duke angry send.home 3.Obj 'The Duke of Qi and Concubine Cai took a boat at a park...The duke was angry and sent her home'

\begin{tabular}{|c|c|c|c|c|c|c|c|}
\hline b. 是 & 歲 & 也， & 海 & 多 & 大 & 風 & (國語•魯語上) \\
\hline $\begin{array}{l}\text { Shì } \\
\text { this }\end{array}$ & $\begin{array}{l}\text { suì } \\
\text { year }\end{array}$ & $\begin{array}{c}\text { yě, } \\
\text { PART }\end{array}$ & $\begin{array}{l}\text { hăi } \\
\text { sea }\end{array}$ & $\begin{array}{l}\text { duō } \\
\text { many }\end{array}$ & $\begin{array}{l}\text { dà } \\
\text { great }\end{array}$ & $\begin{array}{l}\text { fēng } \\
\text { wind }\end{array}$ & \\
\hline
\end{tabular}


'This year, there are many gales over the sea'

The other type of moved topics is LDs which display three properties: 1) they can be phrases other than DPs; 2) they do not require obligatory resumptive pronouns; and 3) they are preceded by complementisers.

As mentioned previously, predicates fronted to the CP area are not restricted to DPs, because they permit AdjPs as well. Furthermore, preposed objects are not limited to DPs either, as they can be TPs too. Therefore, preposed AdjP predicates and TP objects should be postulated as LDs, as in (34a) and (34b) respectively.

$\begin{array}{lccc}\text { (34) a. 善 } & \text { 哉 } & \text { 汝 } & \text { 問 } \\ \text { Shàn } & \text { zāi } & \text { rŭ } & \text { wèn } \\ \text { good } & \text { PART } & \text { 2.Gen } & \text { question } \\ \text { 'Your question is good' } & & \end{array}$

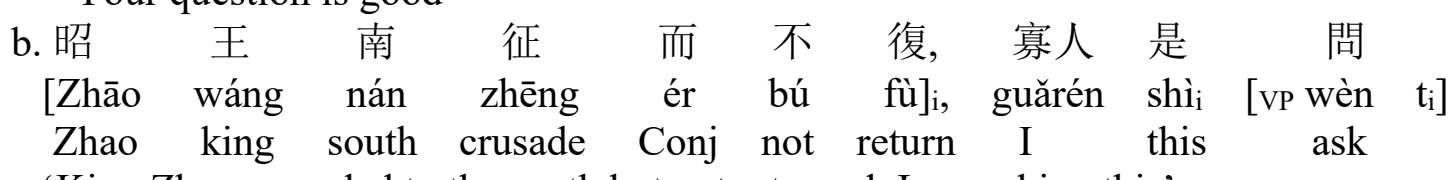

'King Zhao crusaded to the south but not returned, I am asking this'

(左傳・僖公四年)

As regards the second property, LDs in Mandarin require resumptive pronouns when they correspond to objects (Badan and Del Gobbo 2011), yet LDs in Classical Chinese always have an option to leave resumptive pronouns empty, even if being linked to objects. For instance, in (35), although the DPs function as direct objects, when they move out of the low IP area to the left periphery, they do not correspond to any resumptive pronoun in the comment, so external topics like those in (35) are treated as LDs.

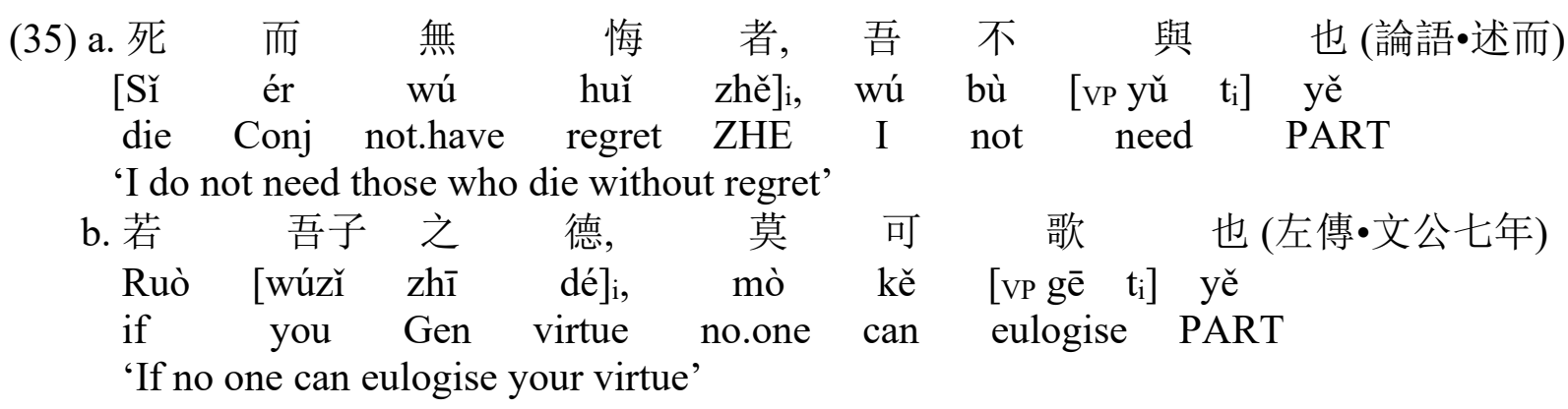

In terms of the third feature of LDs, it indicates that if a LD and a complementiser coexist, the complementiser always precedes the LD. As can be seen from Example (35b), COMP precedes the DP in the CP domain, so this external topic should be regarded as a LD. This statement coincides with the previous analysis of (35b) as a LD based on the second feature.

It is worth mentioning that the relative order between topics and foci in Classical Chinese shows that topics are located in structurally more prominent positions than foci. This observation coincides with that in modern Mandarin (Paul 2005, 2006, Hsu 2008, Badan and Del Gobbo 2011, Cheung 2013). 


\section{CONCLUSION}

In this research, I explore non-wh constructions functioning as internal and external topics in Classical Chinese and suggest that topics in Classical Chinese and those in modern Mandarin can be analysed in line with each other.

In the low IP area, pronoun fronting in the context of negation is a robust feature of Classical Chinese. Pronoun fronting to negation in Classical Chinese is parallel to object preposing in modern Mandarin, in that both phenomena involve zero marking and [ \pm human] DPs and both structures are derived from movement. Since preposed objects without marking in modern Mandarin are internal topics (Paul 2002), I hypothesise that pronouns fronted to negation should also be internal topics. To reinforce my argument, I compare pronoun fronting to negation with foci marked by ZHI/SHI and point out that these two constructions require distinct types of preposed elements and display disparate relative orders with negation; furthermore, the latter, but not the former, is compatible with an 'even' focus interpretation. Moreover, pronoun fronting to negation is in contrast to WEI...ZHI/SHI cleft, in that only the latter exhibits exhaustiveness and bipartition.

In the CP domain, both base-generated and moved topics marked by optional particles are attested from Classical Chinese corpora. Base-generated DPs in the left periphery are not linked to any element in the rest of the sentence, so they are presumed to be ATs. Additionally, these base-generated ATs can be further divided into two subcategories based on their 'possessive' or 'whole-part' interpretation. An object or predicate raising from its base position in the sentence-internal domain to the sentence-initial position preceding the subject, however, always corresponds to a gap or a resumptive pronoun in the rest of the sentence, and the coreferential relation between the preposed object/predicate and its resumptive pronoun/gap is subject to locality constraints. Due to these features, fronted objects and predicates are postulated to be moved external topics. Discrepant from internal topics that are exclusively pronouns and from base-generated external topics that are restricted to DPs, moved external topics permit object/predicate DPs, predicate AdjPs, as well as clausal objects. Furthermore, moved topics in the CP area can be categorised into HTs and LDs, depending on the types of phrases they allow, presence/absence of resumptive pronouns, as well as their relative orders with complementisers.

In this research, I have investigated Classical Chinese that has robust linguistic properties yet is less analysed than its modern counterpart. Through comparing and contrasting Classical and Contemporary Chinese within a historical syntactic framework and via corpus linguistic methodologies, the features and changes of the Chinese language in different periods have been revealed. Further research on the similarities and differences between Classical Chinese and modern Mandarin can be conducted in the future.

\section{REFERENCES}

Aldridge, E. (2010). Focus and Archaic Chinese Word Order. In The Proceedings of the $22^{\text {nd }}$ North American Conference of Chinese Linguistics (NACCL-22) and the $18^{\text {th }}$ Annual Meeting of the International Association of Chinese Linguistics (IACL-18), vol. 2, ed.

L. E. Clemens and C-M. L. Liu, 84-101.

Aldridge, E. (2013). Survey of Chinese Historical Syntax: Pre-Archaic and Archaic Chinese. Language and Linguistics Compass 7, 58-77.

Aldridge, E. (2015). Pronominal Object Shift in Archaic Chinese. In Syntax over Time: Lexical, morphological and information-structural interactions, eds. Theresa Biberauer and George Walkden, 350-370. Oxford University Press. 
Badan, L. and F. Del Gobbo. (2011). On the syntax of topic and focus in Chinese. In Mapping the left periphery, eds. Paola Benincà and Nicola Munaro, 63-90. Oxford: Oxford University Press.

Benincà, P. and C. Poletto. (2004). Topic focus and V2: Defining the CP sublayers. In The Structure of $C P$ and IP, ed. Luigi Rizzi, 52-75. New York: Oxford University Press.

Chao, Y.-R. (1968). A Grammar of Spoken Chinese. Berkeley: University of California Press.

Cheung, C. C.-H. (2008). Wh-fronting in Chinese. PhD dissertation, USC.

Cheung, C. C.-H. (2013). Cong zhitu lilun tansuo hanyu huati yu jiaodian de fenbu [On the distribution of Topics and Foci in Mandarin: a Cartographic solution]. Xiandai waiyu [Modern Foreign Languages] 36.1, 10-17.

Cheung, C. C.-H. (2014). Wh-fronting and the left periphery in Mandarin. Journal of East Asian Linguistics 23.4, 393-431.

Del Gobbo, F. and L. Badan. (2007). On the left periphery of Chinese. Paper presented at the $15^{\text {th }}$ annual meeting of the International Association of Chinese Linguistics (IACL-15) and $19^{\text {th }}$ annual North American conference on Chinese linguistics (NACCL-19), Columbia University, New York.

Djamouri, R. (2000). Preverbal Position of the Pronominal Object in Archaic Chinese. Paper presented at the $9^{\text {th }}$ International Conference on Chinese Linguistics, The National University of Singapore.

Djamouri, R. (2001). Markers of predication in Shang bone inscriptions. In Synchronic and Diachronic Perspectives of the Grammar of Sinitic Languages, ed. H. Chappell, 143171. Oxford: Oxford University Press.

Djamouri, R. (2005). Typological change and word order patterns in Shang inscriptions. Paper presented at the $13^{\text {th }}$ meeting of the International Association of Chinese Linguistics (IACL), Leiden.

Djamouri, R., W. Paul and J. Whitman. (2007). Reconstructing VO constituent order for Proto-Sino-Tibetan. Paper presented at the $18^{\text {th }}$ International Conference on Historical Linguistics, UQAM Montreal.

Djamouri, R., W. Paul and J. Whitman. (2012). Syntactic change in Chinese and the argument-adjunct asymmetry. In Breaking down the barriers: Interdisciplinary studies in Chinese linguistics and beyond, ed. G. Cao, H. Chappell, R. Djamouri and T. Wiebusch, 577-594. Taipei: Academia Sinica.

É. Kiss, K. (1998). Identificational focus versus information focus. Language 74, 245-73.

Ernst, T. and C. Wang. (1995). Object preposing in Mandarin Chinese. Journal of East Asian Linguistics 4.3: 235-260.

Feng, S. (1996). Prosodically constrained syntactic changes in Early Archaic Chinese. Journal of East Asian Linguistics 5, 323-371.

Gundel, J. K. and T. Fretheim. (2006). Topic and focus. In The handbook of pragmatics, $2^{\text {nd }}$ edn, eds. Laurence R. Horn and Gregory Ward, 175-196. Malden: Blackwell.

He, J. and S. Jiang. (1980). Gu hanyu cihuijianghua [Talks on the lexicon of Ancient Chinese]. Beijing: Zhonghua Shuju.

Hole, D. (2012). The information structure of Chinese. In The Expression of Information Structure (The Expression of Cognitive Categories Vol. 5), eds. Manfred Krifka and Renate Musan, 45-70. Berlin: Mouton de Gruyter.

Hou, J. Y.-Y. (1979). Grammatical Relations in Chinese. PhD dissertation, University of Southern California.

Hsu, Y.-Y. (2008). The Sentence-Internal Topic and Focus in Chinese. In Proceedings of the 20th North American Conference on Chinese Linguistics (NACCL-20), ed. M. K. M. Chan and H. Kang, 635-652. Columbus: Ohio State University. 
Huang, C.-T. J. (1982). Logic relations in Chinese and the theory of grammar. $\mathrm{PhD}$ dissertation, MIT.

Huang, C.-T. J., Y.-H. A. Li and Y. Li. (2009). The syntax of Chinese. Cambridge: Cambridge University Press.

Jiang, Z. (1991). Some aspects of the syntax of topic and subject in Chinese. $\mathrm{PhD}$ dissertation, University of Chicago.

Lau, K.-1. (2018). Language Skills in Classical Chinese Text Comprehension. Journal of Psycholinguistic Research 47(1), 139-157.

Li, Y.-H. A. (1990). Order and constituency in Mandarin Chinese. Dordrecht: Kluwer.

Li, C. and S. Thompson. (1976). Subject and topic: A new typology of language. In Subject and topic, ed. Charles. Li, 457-489. New York: Academic Press.

Li, C. and S. Thompson. (1979). Third-person pronouns and zero-anaphora in Chinese discourse. Syntax and semantics: Discourse and syntax, ed. Talmy Givon, 311-36. New York: Academic Press.

Li, C. and S. Thompson. (1981). Mandarin Chinese: A Functional Reference Grammar. Berkeley: University of California Press.

Light, T. (1979). Word order and word order change in Mandarin Chinese. Journal of Chinese Linguistics 7, 149-180.

Meisterernst, B. (2010). Object Preposing in Classical and pre-Medieval Chinese. Journal of East Asian Linguistics 19, 75-102.

Norman, J. (1988). Chinese. Cambridge: Cambridge University Press.

Paris, Marie-Claude. 1998. Focus operators and types of predication in Mandarin. Cahiers de linguistique-Asie orientale 27.2, 139-159.

Paul, W. (2002). Sentence-internal topics in Mandarin Chinese: the case of object preposing. Language and Linguistics 3.4, 695-714. Taipei: Academia Sinica.

Paul, W. (2005). Low IP area and left periphery in Mandarin Chinese. Recherches linguistiques de Vincennes 33, 111-134.

Paul, W. (2006). What the topic is (not) about: the Case of Mandarin Chinese. Ms, CRLAO, EHESS, Paris.

Paul, W. and J. Whitman. (2008). Shi...de focus cleft in Mandarin Chinese. The Linguistic Review 25, 413-451.

Peyraube, A. (1994). On the history of Chinese locative prepositions. Zhongguo jing nei yuyuan ji yuyanxue 2, 361-387.

Peyraube, A. (1996). Recent Issues in Chinese Historical Syntax. In New Horizons in Chinese Linguistics, eds. C.-T. J. Huang and Y-H. A. Li, 161-214. Dordrecht: Kluwer.

Peyraube, A. (1997). On word order in Archaic Chinese. Cahiers de linguistique Asie Orientale 26.1, 3-20.

Peyraube, A. (2008). Ancient Chinese. The Ancient Languages of Asia and the Americas. 136-162.

Qu, Y. (1994). Object noun phrase dislocation in Mandarin Chinese. PhD dissertation. Vancou University of British Columbia.

Shi, C. (1986). Hanyu Yufa Shi Gangyao [An Introduction to Classical Chinese]. Shanghai: Huadong Normal University Press.

Shi, D. (200)0. Topic and Topic-Comiment Constructions in Mandarin Chinese. Language 76.2, 383-408.

Shyu, S.-i. (1995). The syntax of focus and topic in Mandarin Chinese. PhD dissertation, Los Angele University of Southern California.

Shyu, S.-i. (2001). Remarks on object movement in Mandarin SOV order. Language and Linguistics 2.1, 93-124. 
Sun, C. and T. Givón. (1985). On the so called SOV word order in Mandarin Chinese: A quantified text study and its implications. Language 61, 329-351.

Tsao, F.-F. (1978). Subject and topic in Chinese. In Proceedings of Symposium on Chinese Linguistics, 1977 Linguistic Institute of the Linguistic Society of America, eds. R. Cheng, Y. Li and T-C Tang, 165-196. Taipei: Student Book Co.

Tsao, F.-F. (1979). A functional study of topic in Chinese: The first step towards discourse analysis. Taipei: Student Book Co.

Tsao, F.-F. (1987). A topic-comment approach to the ba construction. Journal of Chinese Linguistics 15, 1-54.

Tsao, F.-F. (1990). Sentence and clause structure in Chinese: A functional perspective. Taipei: Student Book Co.

Tsai, W.-t. D. (2000). Object fronting and focus placement in Chinese. Paper presented at the International Symposium on Topic and Focus in Chinese. Hong Kong: Hong Kong Polytechnic University.

von Prince, K. (2012). Predication and Information Structure in Mandarin Chinese. Journal of East Asian Linguistics 21.4, 329-366.

Wang, A. (2013). Object Preposing in Late Archaic Chinese. York Papers in Linguistics 13, 70-98.

Wang, A. (2015). The Intervention Effect of Negation on Wh-Adverbials in Late Archaic Chinese. The Second Asian and European Linguistic Conference Proceedings, 160-172.

Wang, L. (1958). Hanyu shigao [History of Chinese]. Reprinted in 2004. Beijing: Zhonghua Shuju.

Wang, J., S.-m. Wu, S. Jiang and F. Hsueh. (2007). Classical Chinese primer. Hong Kong: Chinese University Press.

Wei, P.-c. (1990). Han Wei Liuchao Zhidaici Yanjiu [Research on Pronouns of the Han, the Wei and the Six-Dynasty Periods]. PhD Dissertation, Taiwan University.

Xu, L. and T. D. Langendoen. (1985). Topic structures in Chinese. Language 61, 1-27.

Yu, M. (1989). The Origins of Verb-Object Inversion. In Yumin Yuyanxue Lunwenji [Collection of Linguistic Works by Yu Min], 288-294. Ha'erbin: Heilongjiang Renmin Chubanshe.

Zhang, N. (1997). Syntactic dependencies in Mandarin Chinese. PhD dissertation, University of Toronto.

\section{$\underline{\text { AUTHORS' BIO }}$}

Aiqing Wang, Ph.D. is currently employed by Lancaster University as a Senior Teaching Associate in Chinese Studies. After graduating with a Master of Arts in Linguistics from University College London, she received a PhD in Linguistics from the University of York, and her doctoral project investigated Late Archaic Chinese syntax. Apart from syntax, her ongoing research interests also include cultural studies. 